\title{
COST-EFFECTIVE APPROACH TO ESTIMATE UNREPORTED DATA: REBUILDING HISTORY OF LIFT-NET FISHING IN KWANDANG WATERS
}

\author{
Andhika Prima Prasetyo, Duto Nugroho, Lilis Sadiyah, Rudy Masuswo Purwoko, \\ Ria Faizah and Agus Setiyawan \\ Research Centre for Fisheries Management and Conservation, Jakarta \\ Received April 29-2014; Received in revised form November 12-2014; Accepted November 14-2014 \\ E-Mail: dhika_fishery@yahoo.com
}

\begin{abstract}
This paper aims to develop cost-effective approach regarding the estimation unreported annual catch data of lift-net fishery using Google Earth imagery. Lift net fishery is one of the main fishing activities of coastal community in Kwandang Bay, it has been faced problem of uncertain fisheries status due to limited recorded data. Combination of a Monte Carlo procedure was applied by involving couple of assumptions on parameters such as estimate growth rate of the total number of lift-net per years (10\%), day at sea per unit per month (21 days) and operated lift-net per month $(50 \%$ and $80 \%)$. The results showed that 101 units of lift-nets were found around Kwandang waters based on Google Earth imagery recorded in October, 7th 2010, and this were used as a benchmark of calculation. This prediction was 28 units higher than official data from North Gorontalo District of Marine Affairs and Fisheries Services (DKP Gorontalo Utara). Compared with capture fisheries statistics issued by Kwandang CFP, the estimated lift-net catches based on two-scenarios represent additional catches of $46 \%$ and $86 \%$. These results suggested and could be used as a correction index to improve the reliability of Kwandang District officially reported fisheries statistics as a baseline to develop a local common fisheries policy.
\end{abstract}

KEYWORDS: Cost-effective approach, unreported data, lift-net fishing, Kwandang waters

\section{INTRODUCTION}

The phrase "fisheries data" generally refers to data that may be of use in the management of a many types of fishery as well as for commercial, recreational, cultural and scientific purposes (NRC, 2000). Fishery statistics are often belong to inaccurate fisheries management (Satria \& Matsuda, 2004; FAO, 2005; Clarke et al., 2006; Zeller et al., 2006, 2007; Erisman, 2011) when implemented as main data on fish stock assessment. However, the historical statistics data could play as a preliminary indicator to describe the general status of existing fisheries. Data played an important role on fish stock assessment which analyzed and interpreted using a broad model to generate practical recommendations (Copper, 2006; Hilborn \& Walter, 1992; Quinn \& Deriso, 1999; ASMFC, 2000). A complicated situation occurred in Indonesia, which a rapid development of fisheries by local government do not accompanied with a better data collecting system which could mislead the local management issues. The uncertain fisheries data were closely related to unsystematic data recording which could sum up as unreported fishing. In many cases unreported data were categorized as part of IUU fishing, which contributes to dramatically long- term decline of the fish resources in the area (Wagey et al., 2009).

To eliminate the unreliable catch data, "reconstructed" approach using diverse data types such as interviews with fishermen, per capita consumption rates, maritime records and other historical data (Zeller et al., 2007) were applied to this fishery. This study attempted to describe far more representatives of marine resources status than previously estimated, and provided critical insights for decision making processes in fisheries management (Al-Abdulrazzak \& Pauly, 2013).

Google Earth which providing free satellite imagery was used as valuable multidisciplinary tool for examining a number of questions including ecological theory (Hughes et al., 2011; Madin et al., 2011), ground-checking aquaculture production (Trujillo et al., 2012), estimating forestry biomass (Ploton et al., 2012), and assessing looting in archeological sites (Pringle, 2010). Satellite imagery also helps us to investigate areas which are remote or expensive-or even prohibited-to access. Satellite imagery via Google Earth allows fishing gears deployed at the surface, such as lift-net, to be seen in coastal regions of Kwandang (Figure 1). 


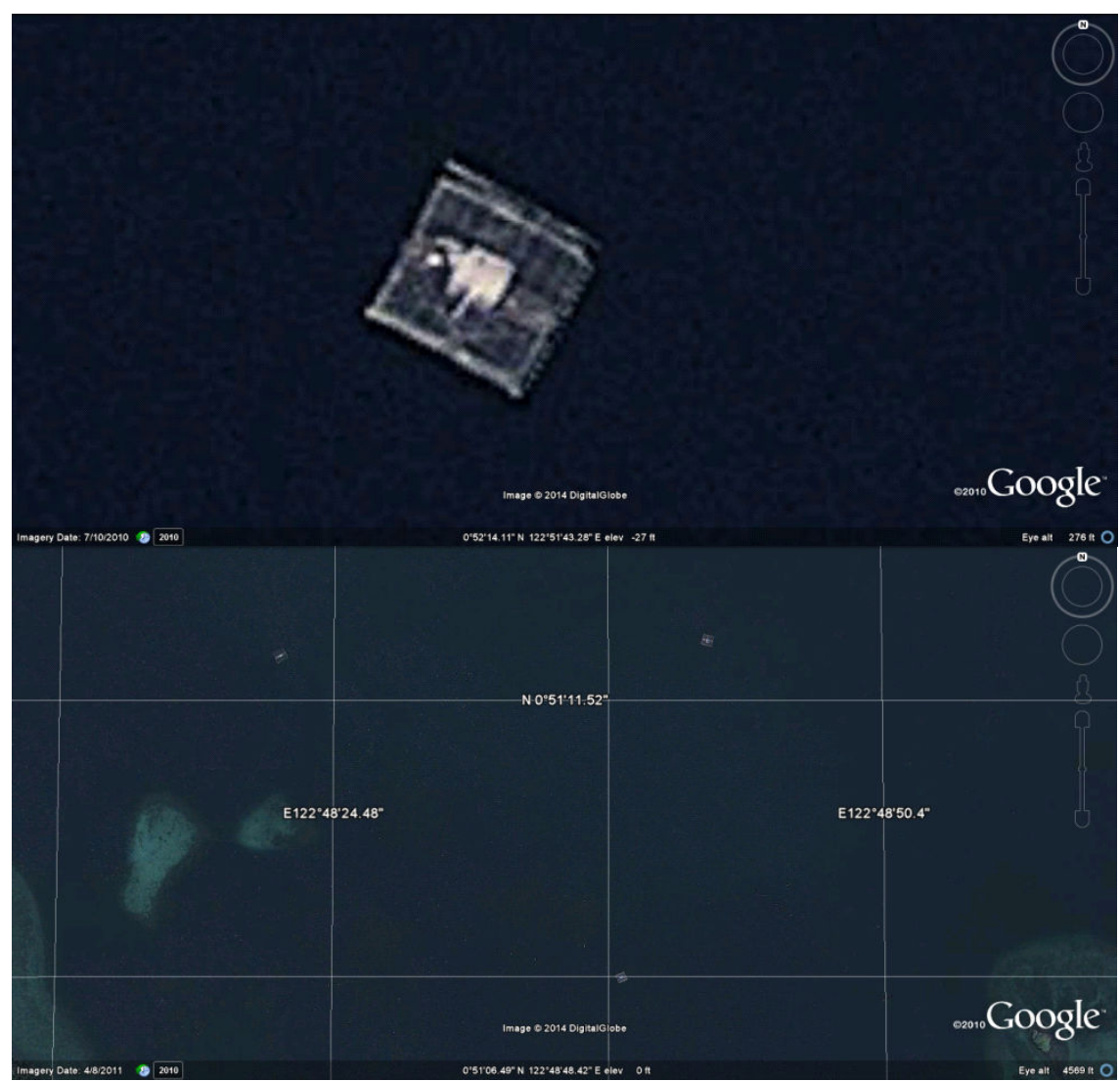

Figure 1. Example image from Google Earth showing a boat lift-net off the coast of Kwandang. Google earth V 7.1.2.2041. (August 4, 2011). Gorontalo, Indonesia. 051'06.49"N, $122^{\circ} 48^{\prime} 48.42 " E$. DigitalGlobe 2014. http://earth.google.com [March 18, 2014].

The exploitation of small pelagic fishes by using Lift-nets was introduced in 1950 by Makassar fishers. Short period lift-nets fishing operation have been popular in Indonesian waters (Subani \& Barus, 1989). Lift-nets have been modified over time such as type, size, design, auxiliary equipment, etc. Generally, liftnets have 2 categories i.e. set lift-net and floating liftnet (Baskoro, 1999); floating lift-nets also consist of 4 categories i.e. one-boat lift-net, two-boat lift-net, raft lift net and motorized lift-net. Although, lift-nets differ on performance, their basic purpose is to capture fish by concentrating fish school using light and limiting their movement by pulling the net vertically (Subani \& Barus, 1989). Mostly lift-nets were targeted smallpelagic fishes as a target species, the fishing was limited by lunar cycle. Traditionally, they were built from woven date palm, but nowadays made from bamboo. However, their contribution to catches may be assessed erroneously for reasons related to their mode of operation (as a semi-active gear, they are lumped with the often neglected small-scale fisheries), market chain and data recording scheme.

In Kwandang, all fisheries were facilitated by Coastal Fishing Port (CFP). Kwandang fisheries was dominated by small-pelagic fisheries i.e. purse seine, drift gill-net, lift-net, pelagic danish seine and handline. In 2013, number of lift-net was 73 units (MFS, Marine and Fisheries Service of North Gorontalo District, 2014). This research aims to develop costeffective approach on estimating unreported catch data of lift-net using Google Earth imagery.

\section{METHODS}

This studies were carried in northern waters of Gorontalo District, Gorontalo Province; especially coastal waters of Kwandang District. Google Earth imagery was available for the Kwandang waters for the year 2010. So, we estimated catches using combination of imagery in 2010 and data recording in 2011 as a benchmark which is provided by Kwandang Port Authority. Data gathering was carried out the coast of Kwandang Bay and marked each lift-net with the Google marker tool. We also measure lift-net frame using the Google ruler tool calibrated to tennis courts (Trujillo et al., 2012).

Data analysis consisted of 4 main steps i.e. data referencing, expert judgments, Google Earth imagery 
and field survey. Each also consists of specific task to gather data and information. Corrected catches was obtained from the result of combining estimating parameters and counting scenarios using Monte Carlo procedure (Figure 2).

Monte Carlo is the approach that uses random number, probability and statistic to counting or estimating value or solution (Nadinastiti, 2011). Generated random number was used to improve accuracy (Achmad, 2012).

Table 1. Initial value of parameters on lift-net fisheries
This analysis has assumption in order to keep model simple but representative i.e. (1) distribution of lift-net was limited; (2) fishing season was calculated from catch data. There also initial value for several parameters to support analysis (Table 1). In order to validate Google imagery, onboard survey also conducted. There are also two scenarios on operated lift-net per month (\%) to estimate the actual catch i.e. $50 \%$ and $80 \%$.

\begin{tabular}{clcl}
\hline No. & \multicolumn{1}{c}{ Parameters } & Value & \multicolumn{1}{c}{ Comments } \\
\hline 1 & Initial number of lift-net (unit) & 101 & Google Earth (Oct, $7^{\text {th }}$ 2010) \\
2 & Growth rate of lift-net per years (\%) & 10 & Interview \\
3 & Day at sea per month (days) & 21 & Interview \& Logbook \\
4 & Operated lift-net per month (\%) & $50 \& 80$ & Interview \& Expert adjustment \\
\hline
\end{tabular}

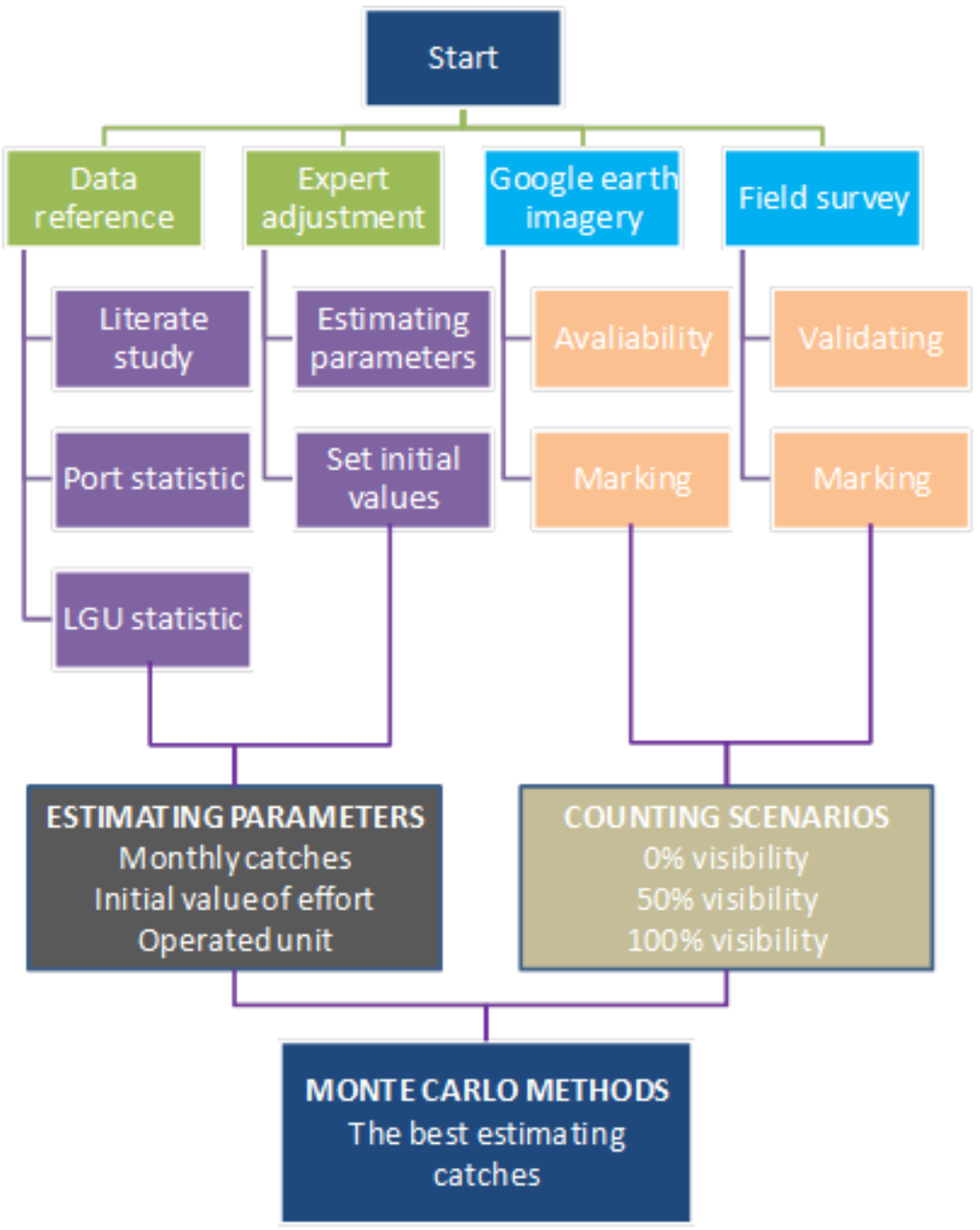

Figure 2. Analysis process of the research. 
Accuracy of this method was influenced by several factors, such as (1) satellite imagery, as tropical country Indonesia has concern on cloud coverage, (2) accurate initial value which was influenced by representative respondent and interview method, (3) validating satellite imagery by conducting appropriate ground-checking, (4) considering in type of fishing gear (fix, semi-dynamic or dynamic) for building basic assumption, and (5) accuracy of Monte Carlo method increasing as impact of increasing random numbers.

\section{RESULTS AND DISSCUSION Results}

Image analysis indicated that there are 101 units of lift-nets were plotted around Kwandang Bay based on October, 7th 2010 Google Earth imagery recorded (Figure 3).

It was 28 units higher that official data from local Marine and Fisheries Service and tends to be constant in each year (Table 2). Compared with statistic issued by Kwandang CFP, these estimated lift-net catches represent additional catches of $46 \%$ and $86 \%$ from two scenarios (Appendix 1).

The majority of the lift-net was located in near the coastal during Google observation on October, 7th 2010. During field survey we also found many lift-net distribute in western part of Kwandang waters. The distribution was depending on wind condition, fish distribution, fish abundance and experience (Daud pers comm, 2013). Lift-net in Kwandang has length and width at $14.7 \pm 1.9 \mathrm{~m}$ and $13.4 \pm 1.5 \mathrm{~m}$ respectively.

Catch composition of lift-net was dominated by small-pelagic fishes such as Stolephorus spp. (51.9\%), Sardinella spp. (17.6\%), Decapterus spp. (13.8\%), Rastrelliger spp. (9.2\%) and other fishes (7.5\%) (Figure 4). The anchovy caught by lift-net was locally marketed in order to supply fish drying processor, anchovy also bought by pole and line fleet for their live bait. Trading at sea and direct landing to processing plant contributed to unreported fisheries data.

Monte Carlo simulation was applied to monthly catches by generating random number for effort (trip) corrected by Google Earth and catch per trip. Simulation has successful to estimate unreported data by providing the best data on the real number of liftnet which operated in Kwandang waters. Figure 5 shows comparison between actual catch and corrected catch. Scenario 1 where we set initial value for percentage of operated lift-net per month is $50 \%$, we found that catch $46 \%$ higher than reported catch. Scenario 2 shows that $80 \%$ operated lift-net will provide $86 \%$ higher than reported catch.

Table 2. Number of small pelagic fishing gear in the waters around district of North Gorontalo

\begin{tabular}{cccccccccc}
\hline Fishing Gear & $\mathbf{2 0 0 5}$ & $\mathbf{2 0 0 6}$ & $\mathbf{2 0 0 7}$ & $\mathbf{2 0 0 8}$ & $\mathbf{2 0 0 9}$ & $\mathbf{2 0 1 0}$ & $\mathbf{2 0 1 1}$ & $\mathbf{2 0 1 2}$ & $\mathbf{2 0 1 3}$ \\
\hline Purse seine & 27 & 37 & 27 & 23 & 23 & 23 & 23 & 23 & 23 \\
Drift gill-net & 362 & 211 & 171 & 507 & 507 & 507 & 507 & 507 & 507 \\
Lift-net & 52 & 71 & 64 & 73 & 73 & 73 & 73 & 73 & 73 \\
Pelagic danish seine & 56 & 32 & 38 & 51 & 51 & 31 & 31 & 31 & 31 \\
Handline & 782 & 1,522 & 741 & 65 & 1,463 & 1,463 & 1,463 & 1,463 & 1,463 \\
\hline
\end{tabular}

Source: $\quad$ North Gorontalo District Marine and Fisheries Service (2014)

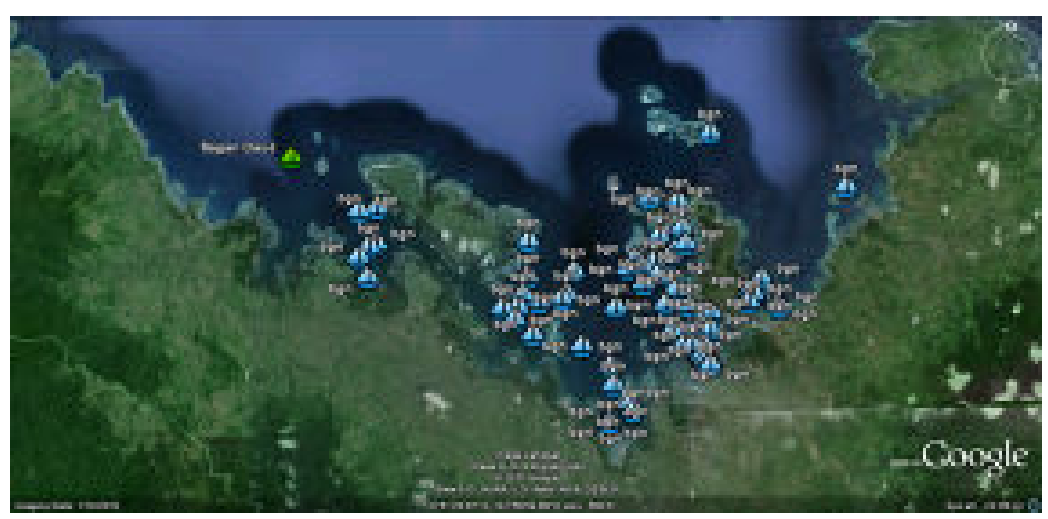

Figure 3. Surveyed coast of the Kwandang waters with assigned "pins" for each visible lift-net. Google earth V 7.1.2.2041. (October 1, 2010). Gorontalo, Indonesia. $0^{\circ} 50^{\prime} 32.13 " \mathrm{~N}, 122^{\circ} 53^{\prime} 43.51$ "E. DigitalGlobe 2014. http://earth.google.com [March 18, 2014]. 


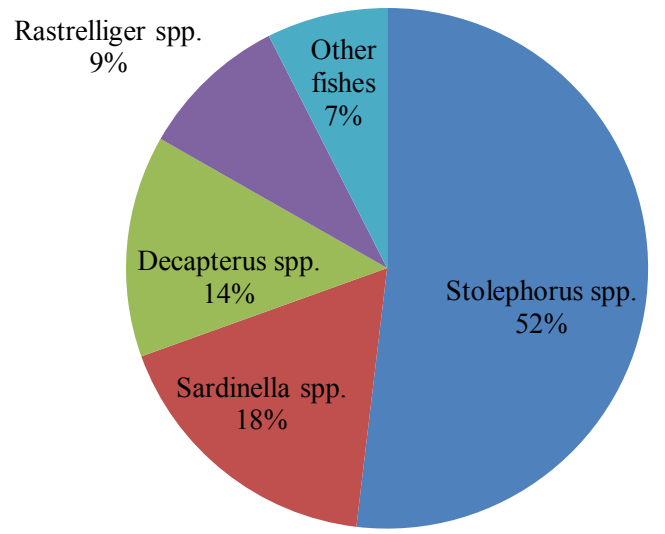

Figure 4. Catch composition of lift-net (Kwandang CFP, 2014).

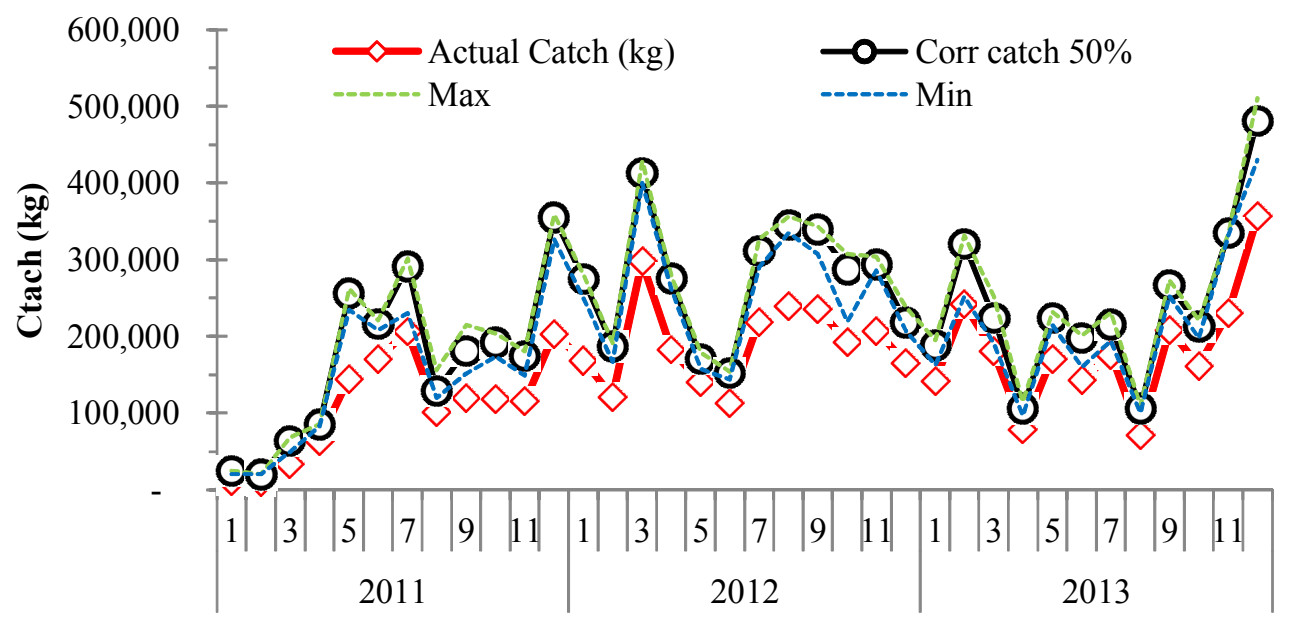

(a)

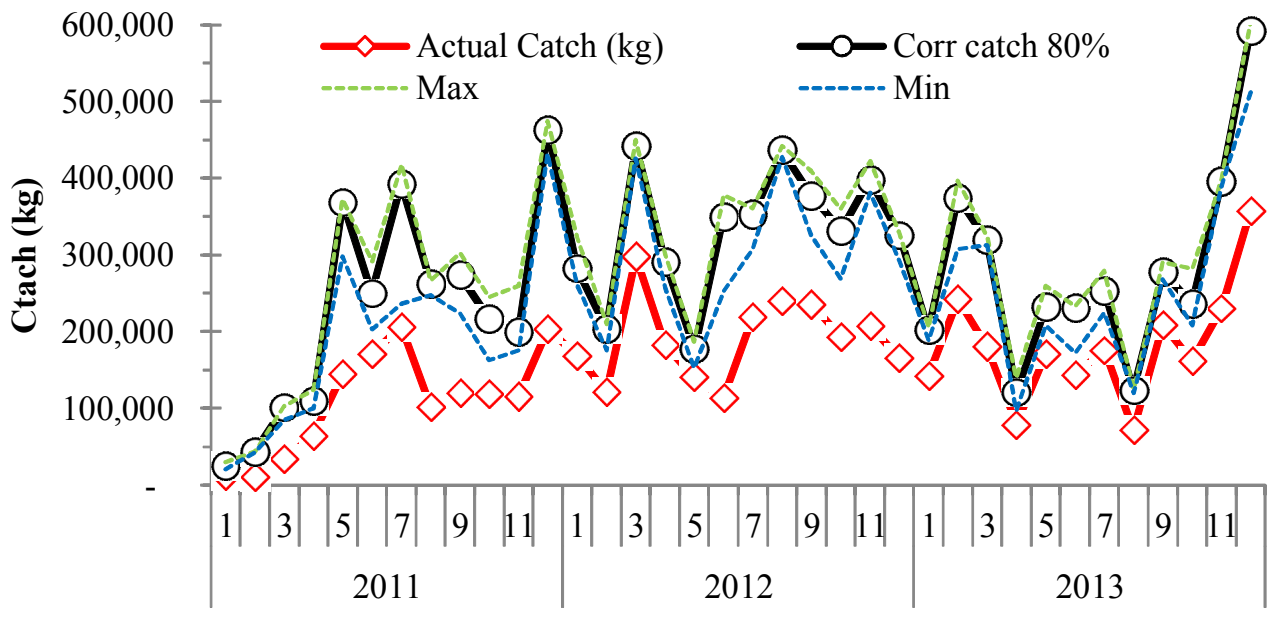

(b)

Figure 5. Comparing actual catch and corrected catch for scenario $50 \%$ operated fleets (a) and $80 \%$ operated fleets.

\section{DISCUSSION}

Combining Google Earth imagery and the best evidence data and information by Monte Carlo method shows us the opportunity to improve fisheries statistical data, especially in Indonesia. As we know,
Indonesia as archipelagic country provides many potential places to develop fisheries industry. That condition are not supported by facilities, human capacity and fisher behave on the importance of data recording. Data was played important role on providing stock assessment by interpreted using model 
generate recommendations (Copper, 2006; Hilborn \& Walter, 1992; Quinn \& Deriso, 1999; ASMFC, 2000). That recommendation was closely related to fisheries management, which is the effort to ensure the resources is sustained to provide benefit to fisheries community in the long term period.

We need to realize that Google Earth imagery provide the best satellite images on recording number of lift-net. Poor satellite imagery (beyond our ability to correct) was the main contribute to the error (e.g. Serjeant, 1968; Jawad, 2006). Management on liftnet fishing has many problems, lift-net fishing does not have license because they used boat $<5 \mathrm{GT}$. That makes lift-net fisheries has growing rapidly in decade. Lift-net using small mesh size net to caught coastal fishes, many of catches was juvenile such as juvenile of Rastreliger kanagurta, Decapterus sp., etc. it also limited reliable data and information on fishing activity of lift-net. It is also because weak or ill-enforced regulations are commonplace.

The research also provides further rationale for reporting catch by gear types (Al-Abdulrazzak \& Pauly, 2013). Fishing gear types are rarely included on calculating impacts on marine ecosystems. In fact, lift-et catches in Kwandang waters consisted mostly of juvenile commercially important species, growth overfishing can occur. These finer scale interactions between marine habitats and fishing gear cannot be discerned by reporting tonnage alone, but using Google Earth can be used to improve the quality of catch reporting and therefore overcome some of these limitations (Al-Abdulrazzak \& Pauly, 2013).

\section{CONCLUSION}

Analysis shows that estimating number of lift-nets around Kwandang waters are 101 units which is based on Google Earth imagery recorded in October, 7th 2010. It was 28 units higher than official data from North Gorontalo District Marine and Fisheries Service. Compared with statistic issued by Kwandang CFP, these estimated lift-net catches represent additional catches of $46 \%$ and $86 \%$ from two scenarios.

Key findings of this research are providing solution on underreporting in the case of the lift-net fisheries in Kwandang waters, which is using freely available satellite imagery. More accurate view of fishery resource use could be providing in order to develop appropriate fisheries management in that area. By combining satellite imagery, robust data and initial parameters we are able to more accurately assess human impacts on marine ecosystems. Using satellites imagery which is have global coverage and periodically monitored images over the same area, they provide a cost-effective way to monitor certain areas of the world over time.

\section{ACKNOWLEDGMENTS}

This research was conducted under the project titled "The Implementation of Tarakan East Kalimantan Demonstration Site of The SCS-SFMP" funded by GEF; implement and executing by UNDP and UNOPS respectively. We also would like thank to port authority of Kwandang by facilitating research, and also Google inc. by providing software.

\section{REFERENCES}

Achmad, Mahmud. 2012. Simulation and Modeling. [Unpublished]. Makassar: Hasanuddin University. [in Indonesia]. 144 pp.

Al-Abdulrazzak, Dalal and D. Pauly. 2013. Managing fisheries from space: Google Earth improves estimates of distant fish catches. ICES Journal of Marine Science November 2013, doi.10.1093/ icesjms/fst178. 5 pp.

\section{ASMFC (Atlantic States Marine Fisheries}

Commission). 2000. Fisheries Stock Assessment User's Manual. Published as Special Report No. 69 by the. Burst, Jeffery C. \& Laura G. Skrobe (eds). $74 \mathrm{pp}$.

Baskoro, M. S. 1999. Capture Process of the Floated Bamboo-Platform Lift net with Light Attraction (Bagan) Graduate School of Fisheries Tokyo University of Fisheries. Post-graduated Program of Marine Sciences and Technology. 149 pp. [in Indonesia].

Cooper, Andrew B. 2006. A Guide to Fisheries Stock Assessment: From Data to Recommendations. Durham: NH Sea Grant College Program. 47 pp.

Erisman, Brad E., Larry G. Allen, Jeremy T. Claisse, Daniel J. Pondella II, Eric F. Miller, Jason H. Murraye. 2011. The illusion of plenty: hyperstability masks collapses in two recreational fisheries that target fish spawning aggregations. Canadian Journal of Fisheries and Aquatic Sciences, 68(10): 1705-1716, 10.1139/f2011-090.

FAO. 2005. Review of the state of world marine fishery resources: FAO Fisheries Technical Paper 457. ISBN 92-5-105267-0. 214 pp. 
Hilborn, Ray \& Carl J. 1992. Walters Quantitative Fisheries Stock Assessment: Choice, Dynamics, and Uncertainty. Champan and Hall. 570 pp.

Jawad, L. A. 2006. Fishing gear and methods of the lower Mesopotamian Plain with reference to fishing management. Marina Mesopotamica, 1: 1-37.

Nadinastiti. 2011. Monte Carlo Method. Report on Probability and Statistic. Technology Institute of Bandung. [in Indonesia]. 5 pp.

National Research Council (NRC). 2000. Improving the Collection, Management, and Use of Marine Fisheries Data. Washington, DC: The National Academies Press.

Quinn, Terrance J. \& Richard B. Deriso. 1999. Quantitative Fish Dynamics. Published by Oxford University Press. 560 pp.

Satria, A. \& Y. Matsuda. 2004. Decentralization of fisheries management in Indonesia. Marine Policy 28 (2004) 437-450.
Serjeant, R. B. 1968. Fisher-folk and fish-traps in alBahrain. Bulletin of the School of Oriental and African Studies, 31: 486-514.

Subani, W \& HR. Barus. 1989. Fish and shrimp fishing gears in Indonesia. Marine Fisheries Research Journal, Special Edition no. 50 1988/1989. Jakarta: Marine Research Institute. 248 pp. [in Indonesia].

Trujillo, P., Piroddi, C., and Jacquet, J. 2012. Fish farms at sea: the ground truth from Google Earth. PLOS ONE, 7: e30546.

Wagey, G.A., S. Nurhakim, V.P.H. Nikijuluw, Badrudin, T.J. Pitcher. 2009. A Study of Illegal, Unreported and Unregulated (IUU) Fishing in the Arafura sea, Indonesia. Research Center for Capture Fisheries, Agency of Marine and Fisheries Research, Ministry of Marine Affairs and Fisheries. ISBN: 978-9791156-14-1. $64 \mathrm{pp}$. 
Appendix 1. Analysis on developing corrected catch data from lift-net fisheries in Kwandang waters.

\begin{tabular}{|c|c|c|c|c|c|c|c|c|c|c|c|c|c|c|c|c|c|c|c|c|}
\hline \multirow[b]{2}{*}{$\begin{array}{l}\text { Month- } \\
\text { Year }\end{array}$} & \multirow[b]{2}{*}{$\begin{array}{l}\text { Actual Effort } \\
\text { (trip) }\end{array}$} & \multirow[b]{2}{*}{$\begin{array}{c}\text { Actual Catch } \\
\text { (ton) }\end{array}$} & \multicolumn{2}{|c|}{ Catch per Trip } & \multicolumn{2}{|c|}{ Effort (unit) } & \multicolumn{2}{|c|}{ Initial Effort } & \multicolumn{2}{|c|}{ Initial Catch } & \multicolumn{7}{|c|}{ Corr catch $50 \%$} & \multicolumn{3}{|c|}{ Corr ca } \\
\hline & & & Lower & Upper & Lower & Upper & Lower & Upper & Lower & Upper & $\begin{array}{c}\text { Corr catch } \\
50 \%\end{array}$ & Lower & Upper & Stdev & Max & Min & $\%$ & $\begin{array}{c}\text { Corr catch } \\
80 \%\end{array}$ & Lower & Upper \\
\hline Jan-11 & 37 & 12.0 & 0.3 & 0.6 & 2 & 3 & 37 & 63 & 12.0 & 20.4 & 24.6 & 24.5 & 24.8 & 0.2 & 24.9 & 20.6 & 106 & 24.4 & 24.0 & 24.8 \\
\hline Feb-11 & 40 & 11.2 & 0.3 & 0.6 & 2 & 4 & 40 & 84 & 11.2 & 23.5 & 20.3 & 20.3 & 20.3 & 0.0 & 20.5 & 20.2 & 82 & 43.0 & 42.9 & 43.0 \\
\hline Mar-11 & 236 & 33.8 & 0.1 & 0.3 & 11 & 20 & 236 & 420 & 33.8 & 60.2 & 64.4 & 63.7 & 65.1 & 0.7 & 68.6 & 49.6 & 91 & 101.2 & 100.4 & 102.0 \\
\hline Apr-11 & 372 & 64.5 & 0.2 & 0.3 & 18 & 29 & 372 & 609 & 64.5 & 105.6 & 85.3 & 85.2 & 85.4 & 0.1 & 85.6 & 82.7 & 32 & 109.2 & 108.3 & 110.1 \\
\hline May-11 & 595 & 145.0 & 0.2 & 0.4 & 28 & 47 & 595 & 987 & 145.0 & 240.5 & 256.4 & 255.4 & 257.4 & 1.0 & 262.5 & 234.9 & 77 & 368.3 & 365.1 & 371.4 \\
\hline $\begin{array}{l}\text { Jun-11 } \\
\end{array}$ & 555 & 171.0 & 0.3 & 0.5 & 26 & 44 & 555 & 924 & 171.0 & 284.6 & 216.5 & 216.1 & 217.0 & 0.5 & 221.0 & 207.9 & 27 & 250.4 & 247.4 & 253.4 \\
\hline $\begin{array}{l}\text { Jul-11 } \\
\end{array}$ & 375 & 206.6 & 0.6 & 0.9 & 18 & 29 & 375 & 609 & 206.6 & 335.4 & 291.0 & 288.2 & 293.8 & 2.8 & 301.3 & 230.7 & 41 & 392.5 & 385.3 & 399.6 \\
\hline Aug-11 & 469 & 101.4 & 0.2 & 0.4 & 22 & 37 & 469 & 777 & 101.4 & 168.0 & 129.6 & 128.3 & 130.8 & 1.2 & 155.6 & 119.6 & 28 & 262.1 & 261.4 & 262.8 \\
\hline Sep-11 & 356 & 119.8 & 0.3 & 0.6 & 17 & 28 & 356 & 588 & 119.8 & 197.8 & 181.5 & 179.3 & \begin{tabular}{|l|l|}
183.8 \\
\end{tabular} & 2.2 & 215.0 & 151.8 & 52 & 273.7 & 271.0 & 276.4 \\
\hline Oct-11 & 497 & 118.7 & 0.2 & 0.4 & 24 & 39 & 497 & 819 & 118.7 & 195.5 & 192.6 & 191.6 & 193.7 & 1.0 & 203.5 & 173.8 & 62 & 216.5 & 213.8 & 219.3 \\
\hline Nov-11 & 455 & 115.2 & 0.3 & 0.4 & 22 & 36 & 455 & 756 & 115.2 & 191.4 & 175.0 & 173.8 & 176.2 & 1.2 & 180.8 & 149.3 & 52 & 199.5 & 196.5 & 202.5 \\
\hline Dec-11 & 390 & 203.4 & 0.5 & 0.9 & 19 & 31 & 390 & 651 & 203.4 & 339.6 & 355.2 & 353.9 & 356.5 & 1.3 & 359.1 & 326.6 & 75 & 463.0 & 461.4 & 464.5 \\
\hline Jan-12 & 203 & 169.0 & 0.8 & 1.2 & 10 & 14 & 203 & 294 & 169.0 & 244.7 & 275.0 & 273.9 & 276.1 & 1.1 & 281.5 & 251.2 & 63 & 282.5 & 280.4 & 284.6 \\
\hline Feb-12 & 334 & 121.3 & 0.4 & 0.5 & 16 & 22 & 334 & 462 & 121.3 & 167.7 & 186.9 & 186.0 & 187.8 & 0.9 & 190.8 & 166.7 & 54 & 203.5 & 202.2 & 204.8 \\
\hline Mar-12 & 628 & 297.7 & 0.5 & 0.7 & 30 & 41 & 628 & 861 & 297.7 & 408.2 & 412.6 & 411.6 & 413.5 & 0.9 & 428.5 & 399.6 & 39 & 441.9 & 440.9 & 442.8 \\
\hline Apr-12 & 594 & 182.8 & 0.3 & 0.4 & 28 & 40 & 594 & 840 & $\begin{array}{l}182.8 \\
\end{array}$ & 258.5 & 275.9 & 275.2 & 276.5 & 0.6 & 279.2 & 261.8 & 51 & 291.3 & 289.7 & 293.0 \\
\hline May-12 & 735 & 140.0 & 0.2 & 0.3 & 35 & 48 & 735 & 1008 & 140.0 & 192.0 & 171.7 & 170.8 & 172.5 & 0.9 & 179.2 & 157.7 & 23 & 177.2 & 176.0 & 178.4 \\
\hline $\begin{array}{l}\text { Jun-12 } \\
\end{array}$ & 670 & 113.8 & 0.2 & 0.2 & 32 & 44 & 670 & $\begin{array}{l}924 \\
\end{array}$ & 113.8 & 157.0 & 152.3 & 151.9 & 152.7 & 0.4 & 154.0 & 144.1 & 34 & 349.2 & 344.5 & 354.0 \\
\hline Jul-12 & 864 & 219.5 & 0.3 & 0.4 & 41 & 58 & 864 & 1218 & 219.5 & 309.5 & $\begin{array}{l}311.7 \\
\end{array}$ & 310.6 & 312.9 & 1.2 & 327.2 & 290.5 & 42 & 352.8 & 350.7 & 354.9 \\
\hline Aug-12 & 615 & 239.4 & 0.4 & 0.5 & 29 & 41 & 615 & 861 & \begin{tabular}{|l|l}
239.4 \\
\end{tabular} & 335.2 & 345.1 & 344.4 & 345.8 & 0.7 & 356.1 & 335.0 & 44 & 436.7 & 436.2 & 437.2 \\
\hline Sep-12 & 724 & 235.6 & 0.3 & 0.5 & 34 & 48 & 724 & 1008 & 235.6 & 328.0 & 339.3 & \begin{tabular}{|l|l}
337.8 \\
\end{tabular} & 340.7 & 1.5 & 343.7 & 307.2 & 44 & 377.2 & 374.4 & 379.9 \\
\hline Oct-12 & 590 & 192.7 & 0.3 & 0.5 & 28 & 40 & 590 & $\begin{array}{r}840 \\
\end{array}$ & 192.7 & 274.4 & 287.4 & 284.2 & 290.6 & $\begin{array}{l}3.2 \\
\end{array}$ & 307.1 & 219.5 & 49 & \begin{tabular}{|l|l}
331.4 \\
\end{tabular} & 328.2 & 334.7 \\
\hline Nov-12 & 569 & 207.5 & 0.4 & 0.5 & 27 & 39 & 569 & 819 & 207.5 & 298.7 & 293.9 & 293.3 & 294.5 & 0.6 & 304.3 & 286.4 & 42 & 398.6 & 397.1 & 400.1 \\
\hline Dec-12 & 680 & $\begin{array}{l}166.1 \\
\end{array}$ & 0.2 & 0.3 & 32 & 46 & 680 & 966 & 166.1 & 235.9 & 218.7 & 217.7 & 219.7 & 1.0 & 237.9 & 207.5 & 32 & \begin{tabular}{|l|l}
325.6 \\
\end{tabular} & 324.1 & 327.0 \\
\hline Jan-13 & 831 & 142.4 & 0.2 & 0.2 & 40 & 54 & 831 & 1134 & 142.4 & 194.3 & \begin{tabular}{|l|l|}
188.1 \\
\end{tabular} & 186.9 & 189.3 & 1.2 & 194.9 & 163.1 & 32 & \begin{tabular}{|l|l}
201.7 \\
\end{tabular} & 200.9 & 202.6 \\
\hline Feb-13 & 686 & 242.2 & 0.4 & 0.5 & 33 & 45 & 686 & $\begin{array}{l}945 \\
\end{array}$ & 242.2 & 333.6 & 320.8 & 317.7 & 323.9 & 3.1 & 331.3 & 252.1 & 32 & \begin{tabular}{|l|l|l} 
\\
\end{tabular} & $\begin{array}{l}370.8 \\
\end{array}$ & 377.9 \\
\hline Mar-13 & 792 & 180.5 & 0.2 & 0.3 & 38 & 51 & 792 & 1071 & \begin{tabular}{|l|l}
180.5 \\
\end{tabular} & 244.2 & 224.0 & 221.7 & 226.3 & 2.3 & 251.6 & 190.8 & 24 & 319.0 & 318.7 & 319.4 \\
\hline Apr-13 & 577 & 78.9 & 0.1 & 0.2 & 27 & 38 & 577 & 798 & \begin{tabular}{|l|l}
78.9 \\
\end{tabular} & 109.1 & $\begin{array}{l}106.3 \\
\end{array}$ & 105.7 & \begin{tabular}{|l|l|l}
107.0 \\
\end{tabular} & 0.6 & 114.3 & \begin{tabular}{|c|}
96.9 \\
\end{tabular} & 35 & 120.5 & 119.1 & 121.8 \\
\hline May-13 & 673 & 171.3 & 0.3 & 0.4 & 32 & 45 & 673 & 945 & 171.3 & 240.5 & 224.5 & 224.0 & 225.1 & 0.6 & 232.1 & 215.0 & 31 & 232.1 & 230.5 & 233.8 \\
\hline $\begin{array}{l}\text { Jun-13 } \\
\end{array}$ & 705 & 143.4 & 0.2 & 0.3 & 34 & 46 & 705 & 966 & 143.4 & 196.5 & $\begin{array}{l}198.0 \\
\end{array}$ & 196.3 & 199.8 & 1.7 & 200.9 & 160.1 & 38 & 231.3 & 228.6 & 233.9 \\
\hline Jul-13 & 735 & 175.8 & 0.2 & 0.3 & 35 & 47 & 735 & 987 & 175.8 & 236.1 & 216.2 & 215.0 & 217.4 & 1.2 & 231.3 & 194.0 & 23 & 252.8 & 251.1 & 254.5 \\
\hline Aug-13 & 456 & 71.8 & 0.2 & 0.2 & 22 & 30 & 456 & 630 & 71.8 & 99.3 & 106.2 & 105.9 & 106.5 & 0.3 & 109.1 & 100.1 & 48 & $\begin{array}{l}122.9 \\
\end{array}$ & 122.7 & 123.1 \\
\hline Sep-13 & 717 & 209.3 & 0.3 & 0.4 & 34 & 47 & 717 & \begin{tabular}{|l|l|}
987 \\
\end{tabular} & \begin{tabular}{|l|}
209.3 \\
\end{tabular} & 288.1 & 266.9 & 266.2 & 267.6 & 0.7 & 273.3 & 252.7 & 28 & 277.2 & 276.4 & 278.0 \\
\hline Oct-13 & 683 & 161.4 & 0.2 & 0.3 & 33 & 45 & 683 & 945 & 161.4 & 223.3 & 212.8 & 212.1 & 213.6 & 0.8 & 220.8 & $\begin{array}{ll}197.8 \\
\end{array}$ & 32 & 236.4 & 233.7 & 239.0 \\
\hline Nov-13 & 727 & 230.3 & 0.3 & 0.4 & 35 & 47 & 727 & \begin{tabular}{|r|}
987 \\
\end{tabular} & 230.3 & 312.6 & \begin{tabular}{|l|}
334.6 \\
\end{tabular} & 334.5 & 334.7 & 0.1 & 335.3 & 332.5 & 45 & 395.3 & 394.9 & 395.7 \\
\hline Dec-13 & 836 & 357.0 & 0.4 & 0.6 & 40 & 54 & 836 & 1134 & 357.0 & 484.2 & 480.9 & 478.0 & 483.9 & 3.0 & 510.9 & 430.2 & 35 & 592.1 & 588.5 & 595.8 \\
\hline
\end{tabular}

